\title{
Preparation of the procedure of virtual organization development in construction
}

\author{
Anastasiia Slavina ${ }^{1,{ }^{*}}$ Malik Zhumaev $^{1}$, Yana Chadkina $^{1}$ and Diana Tereshenko ${ }^{1}$ \\ ${ }^{1}$ Moscow State University of Civil Engineering, Yaroslavskoe shosse, 26, Moscow, 129337, Russia
}

\begin{abstract}
The use of virtual structures in the area of CAD may have an impact on the design labour coefficient and on the works cost reduction. When developing and further functioning of virtual structures in organization, there are a number of issues related to the employees search and employment, work with CAD, with staff, payment for activities, acquisition and storage of information, reporting, interaction between the virtual team members, etc. The full activity of project organizations, both within the large and independent companies, requires for new procedural developments based on the information systems. The procedure of virtual structures development and implementation in organization is proposed to resolve this issue.
\end{abstract}

\section{Introduction}

Construction is the industry on which the national economics depends largely. More than 6 millions of people are involved in the construction industry; more than 115 thousands of companies are associated with the tasks of the construction sector of Russia. The significant changes have occurred in the industry over the last years due to a number of economic reforms. Nowadays the companies, including the construction ones, have to meet the certain rules of information acquisition, processing and storage; in the other case, even the most powerful company ceases to exist. A lot of new software appears, allowing performing the design of construction facilities, calculating the load and cost in less time; however, it requires for programs, which take into account a wide range of works, construction materials with different characteristics, etc. The information support of the construction is the main task for successful development of the industry [1-3].

The construction organizations activity analysis has specified the basic issues of the construction industry:

- the use of obsolete technologies in a competitive environment;

- low percentage of new technologies implementation, involving the works quality degradation;

- high cost of construction materials transportation from the site of manufacture to the construction site;

- inadequate production output and lack of capacities [4,5].

\footnotetext{
*Corresponding author: SlavinaAY@mgsu.ru
} 
The system of preparation for the work certain types performance, provision of all types of resources, development of the procedure and order of processes performance, work with the construction process participants, the quality of work performed - all this issues are combined in the construction operations arrangement. The design takes on the project development, i.e. the development of a new facility with required parameters and documentation. The fundamental difference of design is in the projects management; it is a creative process, which bases on the GOSTs and standards system, and reflects the construction process nature and the design engineer character [6-8].

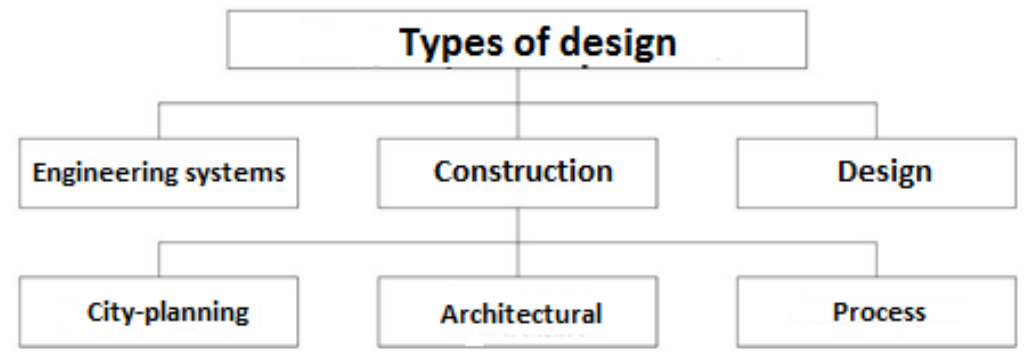

Fig. 1. Types of design.

This research describes the construction design. This is the process, involving the implementation of a certain task in the area of construction, to resolve which the different specialists take part simultaneously (Fig.1.). Nowadays approximately nine thousands of companies work actively at the design market. This fact is the force for creation of more new strategies meant for development of competitive position even if for a short period.

Despite the fact that the project activities in construction may have an impact on the modernization and reconstruction, construction and operation of infrastructure facilities, the quality of projects, the period of their development, the use of technological solutions, resource and energy-saving technologies and design solutions in the projects do not meet the modern requirements to a large extent.

Taking into account all the changes that have occurred in the project organizations within the last few decades, we can talk about the mobility of the project work organization system to achieve the high competitiveness.

Information technologies, as a set of different methods and means, serve as a tool of work with information and provide a completely new level of organization. Automation of systems in construction solves the problem of optimization of work with information; nowadays, , the CAD systems have been developed on the basis of modern computer systems and automation means; these systems are in commercial operation, allowing to a significant extent to free the designer from monotonous, labor-intensive and tedious mental work and to increase his intellectual capabilities at the decision-making stages.

CAD entered completely into the construction organizations life and is an integral part during the project preparation. To develop the high competitiveness in the construction environment, where the work is performed in CAD conditions, it is required for new conditions of design organization, besides the automated systems. The interaction between organizational structure and modern information technologies became a basis for development of a new structure - virtual organization.

\section{Methods}

Dozens of scientific researchers and experts address the issues of organization management. As early as in the beginning of the 20th century the management obtained the 
scientific evidence, which is firstly associated with such names as F. Taylor, F. and L. Gilbreth, H. Emerson, H. Ford.

Three basic principles were selected for the graphical estimate of information flows:

- $\quad$ By type of printing;

- By date of issue;

- By topic-based belonging.

The performed analysis of scientific and practical works in the area of improvement of the project department arrangement and management using the virtual structures shows that this topic is perspective for research. However, the authors describe the theoretical aspect of the organization virtual form activity in the construction inadequately; there is a low percentage of works, describing the experience of virtual structures implementation.

The virtual structure development and arrangement principle is in the use of network approach modifications, where, to implement a specific project, it is required to involve the specialists on a temporary basis without assignment in a certain geographic center, performing the whole work by information technologies. To obtain the first results on this form of work developed was the procedure of virtual structures development and implementation into the existing company.

\section{Results.}

Construction organizations' virtual departments development procedure is given in the Tables 1 and 2 .

Table 1. Construction organizations' virtual departments development procedure.

\begin{tabular}{|c|c|}
\hline Stage & Contents \\
\hline Selection of basis & $\begin{array}{c}\text { Specification of existing organization for the virtual structures } \\
\text { implementation. The selection methods may be different, e.g. the } \\
\text { analytic hierarchy process (AHP). }\end{array}$ \\
\hline $\begin{array}{l}\text { Execution of general } \\
\text { diagram of survey }\end{array}$ & $\begin{array}{l}\text { General diagram of survey is developed together the organization } \\
\text { consultant, and shows the common information on the company, } \\
\text { hierarchical management structure, departments' quantity and staff } \\
\text { composition, availability of affiliates, use of information networks in } \\
\text { work, etc. }\end{array}$ \\
\hline $\begin{array}{l}\text { Execution of plan on } \\
\text { acquisition of } \\
\text { information about the } \\
\text { department staff }\end{array}$ & $\begin{array}{l}\text { Staffing issues shall show the quantity of staff in the selected } \\
\text { department, qualification, experience, personal attributes, etc. }\end{array}$ \\
\hline Questionnaire execution & $\begin{array}{l}\text { The questionnaire purpose is to define the degree of workplaces } \\
\text { virtualization in the department. The first part of questionnaire may } \\
\text { include the questions about the personal data (full name, full age), } \\
\text { education, availability of degree, additional education, length of work, } \\
\text { the second part - about the workplace. }\end{array}$ \\
\hline $\begin{array}{l}\text { Questionnaire } \\
\text { performance and } \\
\text { interpretation of the } \\
\text { results obtained }\end{array}$ & $\begin{array}{c}\text { All staff of the department shall take part in the questionnaire. Then the } \\
\text { department chart is executed and the main characteristics are specified. } \\
\text { The activity virtualization degree is defined, and the list of proposals } \\
\text { on the activity improvement is developed. }\end{array}$ \\
\hline
\end{tabular}




\begin{tabular}{|c|c|c|}
\hline $\begin{array}{c}\text { Execution of procedure } \\
\text { of virtual structures } \\
\text { development in the } \\
\text { department }\end{array}$ & $\begin{array}{c}\text { The following stage, after completion of the stage on specification of } \\
\text { structure diagram and its members, is the selection hardware and } \\
\text { software. Considering that, the software for performance of } \\
\text { construction design tasks is the same, performed is the selection of } \\
\text { systems, allowing maintaining records and monitoring of remote } \\
\text { employees activities. }\end{array}$ \\
\hline $\begin{array}{c}\text { Experimental } \\
\text { implementation of } \\
\text { virtual structure in the } \\
\text { department }\end{array}$ & $\begin{array}{c}\text { The period of implementation, the employees' skills, and the proposed } \\
\text { variants of that who can take part in the experiment are specified } \\
\text { together with the department specialists and administration. The team } \\
\text { coordinator is defined. }\end{array}$ \\
\hline $\begin{array}{c}\text { Obtaining of feedback, implementation procedure is given below. } \\
\text { development of } \\
\text { recommendations }\end{array}$ & $\begin{array}{c}\text { To obtain the feedback, besides the face-to-face communication, it is } \\
\text { possible to conduct survey, where each team member may indicate its } \\
\text { own satisfaction with the activity. Following the results of } \\
\text { questionnaire developed are the recommendations for further work. }\end{array}$ \\
\hline
\end{tabular}

Table 2. Virtual structure implementation procedure.

\begin{tabular}{|c|c|c|}
\hline $\begin{array}{l}\text { Sl. } \\
\text { No. }\end{array}$ & Name of stage & Contents \\
\hline 1. & $\begin{array}{l}\text { General meeting with the } \\
\text { department staff }\end{array}$ & $\begin{array}{l}\text { Kickoff meeting with the department team and } \\
\text { administration. The clarification of experiment tasks, } \\
\text { theoretical and practical basis of the virtual structures. }\end{array}$ \\
\hline 2. & $\begin{array}{l}\text { Selection of a part of staff } \\
\text { for participation in } \\
\text { experiment }\end{array}$ & $\begin{array}{l}\text { The co-decision on selection of the virtual team members } \\
\text { with the head of department. The team selection is performed } \\
\text { as per the existing skills and the personal request. }\end{array}$ \\
\hline 3. & $\begin{array}{l}\text { Specification of scope of } \\
\text { tasks, assignment of roles, } \\
\text { selection of coordinator }\end{array}$ & $\begin{array}{l}\text { Assignment of team coordinators, instructions on the work } \\
\text { with virtual employees, specification of working conditions. }\end{array}$ \\
\hline 4. & Work activity & $\begin{array}{l}\text { Within the specified time, the virtual team carries out its } \\
\text { activities beyond the office. Location - whichever, reporting } \\
\text { of each team - as per the schedule. Communication means - } \\
\text { daily video conference of the team coordinator with the } \\
\text { members and the head of department. }\end{array}$ \\
\hline 5. & $\begin{array}{l}\text { Working meeting after the } \\
\text { project completion }\end{array}$ & $\begin{array}{l}\text { Experiment members kickoff meeting, the feedback by } \\
\text { means of questionnaire survey. }\end{array}$ \\
\hline
\end{tabular}

\section{Discussion}

Responding to the question of the virtual organizations necessity and efficiency, it is worth noting the profit earning due to the specific market order execution speed. The execution speed is provided with pooling the parties' resources in the unified system, where the selected parties - organizations, separate collectives, persons, - have the resources.

Having emerged abroad, today the virtual organizational structures penetrate into the Russian market more and more actively. This happens within both the foreign companies' representative offices and branches, and the domestic companies' structures.

As to the construction industry, nowadays, unfortunately, there are no examples of virtual structures full use for the project implementation, but we can see already the combined efforts of the different production members in order to improve the resources and the finished product quality. Concerning the construction, the virtual work is possible at the design stage. When analyzing the theoretical and practical aspects of virtual structures development and functioning, we defined the following criteria of virtual structures:

1. Flexible work schedule; 
2. Specified work procedure;

3. Mobility;

4. Unavailability of tasks exceeding the specified scope of work;

5. Reduction in expenses for the rent of premises and payment for service staff;

6. Possibility of movement in the virtual teams;

7. Information and communication networks use;

8. Possibility of international cooperation and work with the companies of all levels;

9. Self-selection of projects;

10. Availability of organizational culture;

11. Piecework payment;

12. Continuity of work.

Considering the design-basis nature of work, the wide geographical area, the involvement of a great number of specialists, and non-existence of work schedule as itself, the virtual organization employee is to have the skills set as follows:

1. Flexible thinking and readiness for new tasks execution;

2. Work under the conditions of uncertainty, responsibility, pressure;

3. Selection for one or another solution, selection of the tasks and priorization in its work;

4. Clear specification of the tasks, information;

5. Good written, electronic communication skills;

6. Specification of the aims, its own time arrangement;

7. Knowledge of its activity instructions, fundamental principles of legislation, ethical standards of the company;

8. Communication within the virtual environment;

9. One or several foreign languages skills.

When selecting the employee to the organization with the virtual structure, this employee is to meet the specific criteria. According to the organization aims and the existing projects, the selection algorithm of end performer among the applicants may be developed.

\section{Conclusion}

Within the given context, the method of the virtual structure implementation in the alreadyexisting construction organization department is described as a new form of labor organization, where the remote work is considered not as a permanent form, but as an experimental one required preparing the first results of implementation. The short period allows observing some work aspects and defining the first conclusions only.

\section{References}

1. I.I. Mazur, V.D. Shapiro, Upravlenie rachestvom (Omega-L, Moscow, 2005)

2. S. Bolshakov, S.A. Sinenko, et.al. Industrial and civil construction 8, 87-91 (2016)

3. M. Warner, M. Vytzel, New forms of doing business in the XXI century (Moscow, 2005)

4. A.Y. Slavina, Virtual and augmented reality 2016, 308-314 (2016)

5. S. Bolshakov, Vestnik MGSU 13, 287-294 (2013)

6. V. Serdyuk, Management in Russia and abroad 2, 25-37 (2012)

7. S. Sinenko, A. Slavina, MATEC Web of Conference 106, 08019 (2017)

8. W. Saabeel, Electronic Journal of Organizational Virtualness 4, 1 (2004) 